\title{
Sustainable Population Growth in Low-Density Areas in a New Technological Era: Prospective Thinking on How to Support Planning Policies Using Complex Spatial Models
}

\author{
Eduardo Gomes 1,2,3 (D) \\ 1 Environmental Management Laboratory, Mykolas Romeris University, 08303 Vilnius, Lithuania; \\ eduardojonas@gmail.com \\ 2 Centro de Estudos Geográficos (CEG), Instituto de Geografia e Ordenamento do Território (IGOT), \\ Universidade de Lisboa (UL), 1600-276 Lisboa, Portugal \\ 3 Géographie-cités, Université Paris 1 Panthéon-Sorbonne, 93322 Aubervilliers, France
}

Received: 12 June 2020; Accepted: 7 July 2020; Published: 8 July 2020

\begin{abstract}
Urban development is the result of the interaction between anthropogenic and environmental dimensions. From the perspective of its density, it ranges from high-density populated areas, associated with large cities that concentrate the main economic and social thrust of societies, to low-density populated areas (e.g., rural areas, small-medium-sized cities). Against the backdrop of the new technological and environmental era, this commentary offers insights on how to support spatial planning policies for sustainable urban growth in low-density areas. We propose the integration of technological drivers such as Internet networks, telecommuting, distance-learning education, the use of electric cars, etc. into the complex spatial models to project and thus to identify the best locations for urban development in low-density areas. This understanding can help to mitigate the disparities between high- and low-density populated areas, and to reduce the inequality among regions as promoted in the UN 2030 Agenda for Sustainable Development Goals.
\end{abstract}

Keywords: low-density populated areas; sustainable urban growth; technological era; complex spatial models; land-use planning

\section{Introduction}

Human settlements-i.e., locations where people live, work and/or study-are the result of an interrelated set of dimensions [1]. To recognise the uncertainties surrounding future human settlements, different approaches have been used. Among these approaches, we find that complexity science and geography can contribute to a better understanding of where people will live in the future by providing answers to unpredictable changes and describing how local interactions between individuals in the system shall lead to emerging patterns over time [2-4].

Complexity science, which has been around for roughly seventy years, has been steadily advancing in the past few decades. It integrates interdisciplinary subjects, such as fractals- describing and analysing irregularities [5]; self-organising systems-learning the interactions inside the system, leading to the spontaneous emergence of an intelligible spatial structure without exterior coordination, where there is no hierarchy of command and control, and neither internal or external agents to monitor the process [6]; chaos theory-studying the stability of procedures in response to changes in scale [7]; and cybernetic systems-investigating process regulation as a complex system in an accelerated socio-technological evolution [8]. 
Complexity science and geography have come together to describe, understand, and explain connexions among space-time patterns at multiple scales, linking interactions to nonlinear processes [9]. Hence, they have helped to describe and understand system dynamics, to predict future human behaviour, and they have the advantage of being simple approaches that can incorporate complex analysis. Every stage incorporates complex analysis, involving dynamics, relationships, emergence, and unpredictability. Finding further possibilities for coupling complexity science and geography is one of the most significant challenges that spatial planning needs to face in the future [10]. This engagement has increasingly sparked interest and new knowledge has been established to explore interconnected relationships, unpredictability, and multi-dimension, multi-scale, multi-time, and non-linear thinking [11].

In the past few years, the use of computer simulations employing this two-pronged theoretical approach has been increasing due to its low cost, high speed, and easy reproducibility [12]. Currently, there are plenty of studies indirectly forecasting the growth of human settlements by projecting urban areas, particularly in high-density populated areas contexts, by using complex spatial models, e.g., Fuglsang et al. [13], and Clarke et al. [14]. Nevertheless, in a technological and environmental era, where people can increasingly decide where to live and work [15], and to face to one of the most significant challenges from the spatial planning perspective, the territorial population imbalance between low and high-density areas, there is a lack of the critical thinking needed to study low-density populated areas, identifying different drivers to promote the sustainable urban growth in these areas. Therefore, this commentary casts a light on how using complex spatial models can be effectively applied in land-use planning by promoting new territorial strategies to mitigate the imbalance between high- and low-density populated areas, as support to predict future urban areas growth in low-density populated areas, and to find the most suitable areas. (Figure 1).

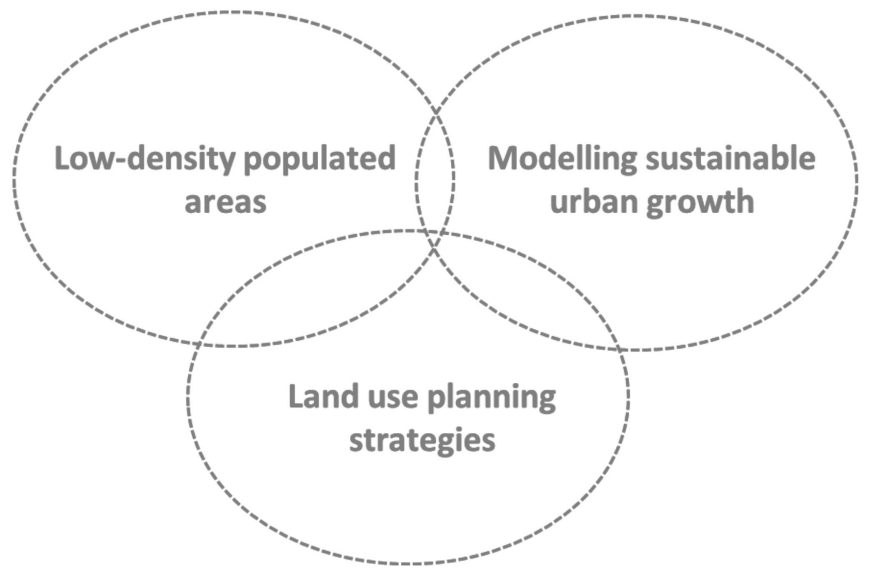

Figure 1. Coupled analysis: low-density populated areas, modelling sustainable urban growth, and land-use planning strategies.

\section{Population Dynamics}

By 2050, around 70\% of the world's population is expected to live in urban areas [16]. Historically, this growth has been associated with urbanisation processes linked to the socio-economic development of the countries [17]. Currently, North America is the region where the most people live in urban areas (82\%), followed by Latin America and the Caribbean (80\%), and Europe (73\%). By country, China has the most prominent urban population (758 million), followed by India (410 million), and the United States of America (263 million). By metropolitan region, Tokyo is the world's largest one with 38 million inhabitants, followed by Shanghai (34 million), and Jakarta (with almost 32 million inhabitants) [16]. Urban population worldwide has overgrown since 1950, from 746 million to 3.9 billion in 2014, and by 2050 , it is expected to reach 6.3 billion, where approximately $90 \%$ of this growth is expected to occur in Africa and Asia. 
Population growth in urban areas throughout history, in different places and stages, has fluctuated both in terms of core and ring. Theoretically, the different stages occur based on four major cycles [18]:

(i) urbanisation: indicates population growth within the city (and associated with a suburbanisation process with low-density settlements in the urban fringe);

(ii) exurbanisation: corresponds to migration away from large cities;

(iii) counterurbanisation, which represents population decrease both within the city and in the urban fringe; and

(iv) reurbanisation: embodies population increase within the city and its decrease in the urban fringe.

These four stages have been identified in different urban areas around the world as a result of a complex interaction between anthropogenic and environmental drivers $[19,20]$, and they have been recognised with different dynamics, morphologies, densities, and spatial locations. For instance, the urbanisation process has been associated with contiguous urban growth around cities, and along highways and roads, connecting suburbs in different forms [21] such as enlarged cities, metapolis, city-regions, and periurban regions. Likewise, from the perspective of morphology, some characteristics have been recognised, such as monocentric (distributed over extensive areas), dispersed (scattered cities), linear (with linear forms of agglomeration), and polycentric urban regions (multiple cities connected) [22]. The urban growth in some of these urban forms leads, frequently, to the emergence of urban sprawl [23], which is defined as a low-density dispersed development outside the compact urban area and beyond the edge of service and employment [24]. Batty [25] defined it in three interconnected concepts of spatial dynamics: the decline of central or core cities; the emergence of edge cities; and the rapid suburbanisation of the peripheries of cities. On the other hand, Torrens [26] refers to it as low-density growing areas along the fringes of metropolitan areas, characterised by their compactness and dispersion. These areas are often identified as the urban expansion into suburban areas and characterised by unplanned [27], uneven growth [28], contiguous suburban growth [29], mixed uses [30], scattered and leapfrog development [26], strip or linear development [31], poly-nucleated nodal development, and both as a state, and a process [32]. Behind these morphological and dynamic changes, different drivers have been identified as the main reasons, such as policy interference and social organisation changes, industrialisation, infrastructure, and a cultural, technological, and/or socioeconomic boost [33].

The urban growth process has implications for land-use sustainability, both from the socioeconomic and environmental perspective [34-36], and they can be both negative and positive. Among the many impacts, the negative ones may be the undesirable effects on public health and quality of life [37], urban pollution increase [38], greater dependence on cars [39], spatial fragmentation [40], and loss of farmlands [41]. The positive ones may be the sense of community between inhabitants [42], more living space [41], decreasing crime rates [39], and the fact that fragmented urban growth has been perceived as an economic expansion [28].

Contrary to the urbanisation-suburbanisation process, exurbanisation represents the mobility of people from large urban areas into rural areas [43]. Exurbanisation as a concept was introduced by Spectorsky [44] and is defined as the ring of wealthy rural communities inhabited by urban professionals, where urban and rural activities are interconnected, and the relocation of residential areas, services, industries, logistic centres, and high-tech zones is the result of a trend towards de-concentration [45]. It represents the area outside the contiguously built-up areas of large cities, outside metropolitan regions, where rural areas are interwoven with small-medium sized cities, and people live by maintaining their urban income [43].

These processes have been led to land-use and land-cover changes and they have been triggered by driving forces. The concept of driving force become well-known in landscape ecology during the 1990s, which was defined as the processes responsible for the landscape changes [46]. Therefore, it can be categorised into the three following stages: 
(i) underlying drivers: such as environmental, policy, technology, socioeconomic, culture, and location;

(ii) processes: related to land manager decisions and behaviours; and

(iii) manifestations of land-use and land-cover change: connected to intensification (e.g., high-density populated areas), and disintensification (e.g., land abandonment).

Many drivers influence land-use transitions, and they are the result of land supply and demand, affecting its patterns, structures, and functions. Some studies have contributed to describe the effects on landscape change [33], and its complex interaction processes [46]. There are plenty of driving forces that may be responsible for those transitions. Table 1 reviews some of these key drivers, from global to local scale.

Table 1. Global, national, and local driving forces.

\begin{tabular}{ccccc}
\hline Scale & Driving Force & Description & Source \\
\hline \multirow{3}{*}{ Global } & World prices & It can influence land-use change decisions. & [47] \\
\cline { 2 - 5 } & Climate change & It represents unpredictability-greater negative impacts. & [48] \\
\cline { 2 - 5 } National & High energy prices & It increases food prices. & [49] \\
\cline { 2 - 5 } & Shortening market & It changes the food demand. & [50] \\
\cline { 2 - 5 } & Water scarcities & It promotes strategies to create irrigated agricultural land. & [52] \\
\hline \multirow{2}{*}{ Local } & Population pressure & It can reduce the agricultural land available for farming. & [53] \\
\cline { 2 - 5 } & Market access & It reflects a stricter price. & [54] \\
\hline
\end{tabular}

Worldwide, landscape has been experienced significant land-use changes. They have been encouraged by different drivers such as political reasons, cultural history, land reforms, and enhanced technological, as well as diverse institutional and economic drivers [33]. The population growth and the need for cropland, grassland, and forest have led to a high level of land-use and land-cover changes. At the same time, spatial patterns of urban development have registered significant changes over the last decades, especially from the fringes of large cities, which have registered high levels of land-use changes from natural and semi-natural areas into artificial land, mostly to residential and tourist settlements, industrial, and commercial surfaces.

Therefore, the understanding of different urban development processes is relevant. The study of sustainable urban growth in exurbanisation processes can encompass multiple disciplines [55] and may be a central key for land-use management to mitigate the disequilibrium between low- and high-density populated areas, by promoting the sustainable urban growth in low-density populated areas. Some of these disciplines may be those related to complexity science and spatial planning to define better policy priorities and endorse inclusive and equitable development [56,57].

\section{Complex Spatial Models}

In the interpretation of urban and population dynamics, different models and methods have been used in the scientific literature. Some of them, such as the classical geographic models have in common the study of interaction, diffusion, migration, and location, identifying the who, what, why, and where. They have been applied in urban economics and social physics, e.g. Von Thünen's model, Weber's model, Walter Christaller's central place formulation, Alonso's model, the gravity model of spatial interaction, Hagerstrand's model, and Tobler's law. The majority of them share the principles of complexity science, which are useful to describe how local interactions between individuals in a system can lead to emerging patterns over time [2].

In the 17th century, René Descartes argued that 'nothing comes out of nothing', and this quote describes very simply how complexity science can be understood. Nevertheless, there is not a 
single definition for complexity science and there is no consensus about it [58]. This is partially since complex system theory itself was only properly recognised in the 1990s [59]. However, it is agreed that complexity science corresponds to a system where a set of entities, processes, and agents interact over an extensive network with no central control [60]. Local interactions between agents and the environment can result in unexpected and unpredictable behaviour at the global level in a new bottom-up approach [61]. These local or global interactions may lead to positive and negative responses that can influence the state of the system [62].

Self-organisation, nonlinearity, and order and chaos were the fields that gave rise to complexity science. In self-organisation, the interactions inside the system lead to the spontaneous emergence of an intelligible spatial structure without exterior coordination, where there is no hierarchy of command and control, neither internal nor external agents that monitor the process [6]. In nonlinearity there is a continuous and discontinuous change, and, the cause-effect relation is disproportional [63]. Lastly, order and chaos is related to unpredictable behaviour in a system in which agents interact randomly with other agents, rather than being planned or controlled [9].

The complex systems evolution often comprises disconnected time-scales. The disconnection or transition is the consequence of an aggregation of techniques of changes, since collective behaviours and relations, and physical, economic, or social configurations cause irreversible changes in a system. Four stages of stability transition have been identified:

(i) pre-development: in which indicators change only slightly, in which does not exist a dynamic of equilibrium;

(ii) take-off and accelerated stage: in which indicators change with growing speed, and the system starts to break;

(iii) breakthrough or acceleration: in which the system changes structurally; and

(iv) stabilisation stage: in which the speed of social change declines and a new dynamic equilibrium is achieved.

These multi-stages provide a straightforward interpretation of what will occur throughout a transition process. The conceptual theory proposes a cyclic pattern, a stabilisation stage, and what could be the predevelopment stage for the next development stage.

Complex systems consider that connexions and interdependencies are challenging to describe, predict, and manage [64], and they are the result of collective behaviour. Complex systems are more than the sum of individual actions [58], and for a system to be called complex, its components have to be self-organised, and it has to be less dependent on environmental actions [65], exploring dynamic systems in a broad and multi-disciplinary context.

Complex systems studies are increasingly used in natural and social sciences and provide a powerful tool with which to capture evidence about the world [66]. More recently complexity science has been studied in policy and evaluation, more specifically in the understanding of collective decision-making [67]. This interconnection has been supported by modelling techniques, in which they have been used to solve complex problems, integrating empirical data, entities, and relations among objects. Models can reproduce experimentally-observed real systems (real world) and can be divided into space and time. In addition, they represent an abstraction of the world and they can be described into three different types:

(i) deterministic, in which the model is entirely defined by the parameter values and the initial conditions, displayed by deterministic rate equations. A deterministic model can be stretched to account for the spatial organisation and has been effectively used to analyse the reaction process [68];

(ii) stochastic, in which they have intrinsic randomness, and the set of parameter values and initial conditions will lead to an ensemble of different outputs; and 
(iii) the hybrid model, which represents a combination of both deterministic and stochastic models. They are used in analysis, optimisation, synthesis, gaining, and in the comparison of alternative systems.

Complex model simulations can help to explain and predict geographic phenomena [69], and they have been used from a new perspective of spatial simulation modelling, to incorporate an accurate representation of geographic space [70-72]. They have been integrated an object-based and spatially-explicit approach linked to complex systems dynamics [73], allowing better understanding of the spatiotemporal phenomena by modelling human behaviour [74].

Complex spatial modelling represents an advance of geographic information science that has contributed to an efficient reflection on new space perceptions $[75,76]$. Predicting and assessing future land-use trajectories enables identification of their causes and consequences [77], involving a multidisciplinary evaluation [78], and integrating a broad range of biophysical, demographic, and socioeconomic drivers $[79,80]$. Currently, there is a variety of complex spatial models based on different empirical techniques, such as equation-based models, system models, evolutionary models, genetic algorithms, cellular automata (CA), artificial neural networks (ANN), and agent-based models $(\mathrm{ABM})$. These last three, have been among the most used in modelling land-use and land-cover changes. CA is defined by cell space, timestep, cell states, cell neighbourhood, and transition rules [81]; ANN are based on a machine learning system and inspired by human brain neurons structure [82]; and ABM enable the reproduction of human actions such as cognition, communication, and learning [83].

These models have been used to simulate land-use dynamics, identifying driving forces for those changes [84], and capturing the behaviour of individuals, integrating simple rules but incorporating complex behaviours. Table 2 shows some examples that combine CA, ANN, and ABM in the study of land-use cover changes.

Table 2. Land-use models based on CA, ANN, and ABM.

\begin{tabular}{|c|c|c|c|}
\hline Method & Model & Description & Source \\
\hline \multirow{3}{*}{$\begin{array}{l}\text { Cellular } \\
\text { automata }\end{array}$} & MOLAND & $\begin{array}{l}\text { Provides a spatial planning tool used to evaluate, to } \\
\text { monitor, and to model urban development at the } \\
\text { regional level. }\end{array}$ & [85] \\
\hline & SLEUTH & $\begin{array}{l}\text { Designed with predefined rules. SLEUTH uses four } \\
\text { types of urban transitions: spontaneous growth; new } \\
\text { spreading-centre growth; edge growth; and } \\
\text { road-influenced growth. }\end{array}$ & {$[86]$} \\
\hline & RIKS & It is developed at two scales: macro and micro level. & [87] \\
\hline \multirow{2}{*}{$\begin{array}{l}\text { Artificial neural } \\
\text { network }\end{array}$} & $\begin{array}{l}\text { GIS-ANN Web - } \\
\text { SECOA }\end{array}$ & $\begin{array}{l}\text { It allows stakeholders to measure land-use } \\
\text { transitions according to different scenarios. }\end{array}$ & {$[82]$} \\
\hline & $\begin{array}{l}\text { Land } \\
\text { Transformation } \\
\text { Model }\end{array}$ & $\begin{array}{l}\text { It projects spatial and temporal patterns of land-use } \\
\text { changes and identifies its driving forces. }\end{array}$ & [88] \\
\hline \multirow{3}{*}{$\begin{array}{l}\text { Agent-based } \\
\text { models }\end{array}$} & PUMA & $\begin{array}{l}\text { It simulates land-use changes based on a land } \\
\text { conversion model and household model. }\end{array}$ & [89] \\
\hline & ILUMASS & $\begin{array}{l}\text { It was developed to run at microscopy level, } \\
\text { simulating land-use changes, transportation, } \\
\text { and environmental dynamics. }\end{array}$ & [90] \\
\hline & RAMBLAS & $\begin{array}{l}\text { It simulates the impacts of land-use changes, } \\
\text { and transportation planning policies. }\end{array}$ & [91] \\
\hline
\end{tabular}

Combining different geographic models allows us to manipulate and create relationships between spatial data, and to integrate deterministic and stochastic predictive analysis to establish artificial relationships between different spatial data [92]. As a result, these models can create spatial knowledge that can subsequently be used as a support for spatial decision-making $[93,94]$. 


\section{Land-Use Planning}

Through the complex spatial models' outcomes, land-use planning can support better-planning practices [95]. It helps us to identify alternatives for land use and adopt the best land-use options, allocating land uses to meet the environmental, social, and economic needs of the population while preserving future resources [96]. It incorporates socioeconomic trends and physical and geographic elements. Land-use planning is a public policy that describes and regulates the use of land to support local development goals and creates legal and administrative instruments that support the plan to define land allocation, zoning, and density of construction. Land-use planning also comprises the anticipation of the need for changes as well as responses to that need, employing strategies to deal with territorial elements, e.g. transport, commercial, industrial, residential, and economic growth, and mitigating and adapting to climate change, as well as protecting people from natural disasters. These strategies must be selected taking into account their efficiency, guarantee equity, safeguard important requisites such as food security, employment, and recognise the current needs of the population, while still preserving resources for future generations [97].

The best principles for land-use planning are those that both decision-makers and stakeholders/ population can debate, identifying the highest consensus on the goals of a specific territory, as well as those that incorporate the largest development vision (larger scale) for the locality (local scale). At a larger scale, land-use planning, in many cases, establishes priorities by balancing the competing demands for land from sectors such as the economy, tourism, housing and public amenities, road network, industries, as well as wildlife preservation. At the local scale, land-use planning should capture local stakeholder knowledge and contributions, as well as local actions [98]. From the perspective of the mitigation of population distribution imbalance, in a region or country, spatial planning measures can be taken at larger and/ or local scale and should encourage sustainable urban development in low-density populated areas.

\section{How to Support Planning Policies to Mitigate the Territorial Imbalance between Low- and High-Density Areas in a New Technological Era?}

While new planning standards such as territorial cohesion or the reduction of inequality within and among countries (as promoted in the UN 2030 Agenda for Sustainable Development Goals) have been encouraged, the increasing socioeconomic distance between rural or small-medium sized cities and large cities has been one of the significant planning challenges [99]. It was found that the lack of effective spatial planning has resulted in uncoordinated strategies and has led to a territorial population imbalance in some regions of the world. Therefore, the study of exurbanisation processes may be useful to identify alternative spatial scenarios; propose and point out guidelines to mitigate urban growth pressure in large cities; and create incentives for people to live in rural areas or small-medium sized cities.

The principle of people's migration from large cities to low-density populated areas related to technological advances has already been discussed by several authors in the past. In the 1990s, Frances Cairncross published a book anticipating "The Death of Distance", in which Cairncross argued that with technological advances we will see a migration of people from urban to rural areas. However, more than 20 years have passed, and this transformation has not yet occurred. In 2012 Enrico Moretti, opposing the idea of Cairncross, argued in his book entitled "The New Geography of Jobs" that the death of distance is a myth. In 2018, this idea was corroborated by Joe Cortright in his article entitled "IoT: The Irrelevance of Thingies", in which Cortright defended that "people and social interaction, not technology, is the key to the future of cities". Partly, we think that the opinion of these both authors is valid (from the premise that large cities will continue to grow), however, we think that with the most recent technological advances, particularly related with the advances on the Internet (e.g. 5G), and with more powerful computers, that new settlements in low-density areas can emerge due to these new advances. In an article recently published by Michael Batty (May 2020), entitled "The Coronavirus Crisis: What Will the Post-Pandemic City Look Like?", Batty argues that the "low-density urban sprawl 
and new communities far from the central city" can be a new reality in the near future [15]. This subject is even more relevant when we are at the beginning of the third decade of the 21st century and are facing new global pressures, such as socioeconomic, climatic, and health challenges. In an era when the divide between high-density populated areas and low-density populated areas has been increasing, new approaches to study this phenomenon are needed. They can encompass new technological drivers such as good Internet access, which is directly connected with telecommuting and distance-learning education (behind the migration from large cities to rural or small-medium sized cities) by integrating it in the complex spatial models approaches, and thus promoting better land-use strategies. Therefore, a concept derived from exurbanisation is proposed. Based on the most recent technological era, where the notion of physical location is changing, the concept of 'cyber-exurbanisation' is proposed. It combines the terminology of 'cyber' or 'cyberspace'-i.e., a non-physical space where people can remotely access a network of information technology—and 'exurbanisation', which represents the migration of people from large urban areas to rural and/or small-medium sized cities. Based on this new opportunity, complex spatial models may play an important role by identifying in a region or country, outside large cities, how, why, when, and where people can live in the future.

Throughout human history, different stages in terms of innovation, technology, culture, and socioeconomic transformations have developed worldwide. The first stage recognised was the industrial revolution, when human labour started to be replaced by machines; the second stage was related to mass production using electric power; the third was associated with informatisation based on computers and the Internet; and the fourth has been linked to artificial intelligence, cyber-physical systems, and the Internet of Things [100]. Additionally, and more recently, some authors have mentioned sustainability as the new revolution that has emerged in the past few years [101]. Sustainability has been studied by the scientific community from different perspectives, such as pollution in cities [102], traffic jams [103], overcrowded cities [104], and food security [34]. In this new era of environmental concerns and technological advances, new lifestyles and new job opportunities have emerged. This era has created new opportunities-one of the most relevant opportunities for people working in a growing number of jobs is the possibility of deciding where they want to live. Therefore, different challenges, opportunities, strengths, and weaknesses are being faced in urban living.

From the socio-economic and technological perspective, there are plenty of drivers that may be responsible for migration movements from large cities to rural areas, or small-medium sized cities, such as housing prices, industry 4.0, telecommuting, distance-learning education, Internet, electric cars, aerial vehicles, and digital medicine, health, and therapeutics. They have all been recognised as drivers to interpret these future human settlements.

Currently, one of the most critical topics related to large cities worldwide is the supply/demand imbalance in the housing market. As a result, housing prices have soared [105]. In 2019, Hong Kong, San Francisco, New York City, Zurich, Paris, and London were ranked as the most expensive cities to buy or rent a home [106]. In some of these cities, middle-class families have lost the power to live inside their boundaries since their disposable income has not followed the same growing trend. This situation has been forcing many people to migrate out of these large cities over the past few years [107] and can contribute as one of the main push factors that encourage people to move from large cities to a 'cyberspace' located in a rural area and/or a small-medium sized city.

With the paradigm of industry 4.0, introduced in the early 2010s [108], new challenges are being faced worldwide. One of them is related to digital and technological employees that have been allowed to work and study remotely [109], and thus they are free to decide where to live [110]. A new technological generation of staff using the capability of the cyberspace has been developing in the past few years. Some technological advances in Internet connection, such as new fibre-optic technology [111] and 5G Internet [112], have increased Internet speed and coverage worldwide. Companies such as Google, Facebook, Airbus, Boeing, and SoftBank, have been working in projects targeted at spreading the Internet to the most remote populated areas worldwide employing satellites, drones, balloons, and airships. Consequently, these technological signs of progress have led us to believe that physical 
distances will be blurred in the near future, allowing people to access the Internet for personal or work purposes in the most remote areas in the world.

Equally as fast have been the recent developments in mobility, particularly in the market of electric cars to transport people, and in the market of aerial vehicles (e.g., drones) to transport goods. These advances have contributed and will further contribute to reducing environmental impacts by cutting $\mathrm{CO} 2$ emissions; lower economic costs by decreasing maintenance and production costs [113]; and increase the mobility of people, goods, and products [114]. Additionally, some other drivers, which do not depend on a person's location, will contribute to reducing the isolation of areas outside large cities, such as digital medicine, health, and therapeutics (allowing practitioners to increase the early identification of diseases) [115]. Therefore, these mentioned drivers can directly or indirectly play a relevant role in the emergence of new inhabitants in rural and small-medium sized cities (out of large cities) in the near future, and they may later shape the new forms of human settlements.

Then, we argue that, apart from the widely used socioeconomic, political, and environmental explanatory variables in the complex spatial models' analysis, we need to integrate these new technological drivers in these analyses. This is even more evident when we are facing, particularly in recent years, increasingly improved technological development. This will allow the projection of a sustainable population growth in low-density areas and in that way, it will allow the demonstration of better alternatives for urban growth and thus better anticipation, interpretation, assessment, and mitigatation of the impacts of the spatial location of future human settlements.

This understanding may be helpful to some governments worldwide, in which they set out to mitigate the imbalanced population distribution in a region or a country; to strengthen territorial equity and territorial cohesion; promote decentralisation of state functions; and to promote a polycentric urban system by increasing the number of cities with supranational polarisation [116]. Thus, anticipation of a better sustainable urban growth in low-density areas can contribute to the creation of better land-use planning strategies; contribute to land-use sustainability [117], and the promotion of territorial cohesion in a country or region.

\section{Conclusions}

Planning strategies are focused on opportunities, organisational strengths, and framing processes. These strategies support decision-makers by enabling them to use skills that will lead to better decisions about future actions [118]. With the help of complex spatial models, it is possible to anticipate and understand future land-use dynamics, and to create land-use strategies accordingly $[53,119]$. In the past two decades, the majority of studies that deal with urban and population growth prediction, complex spatial models, and spatial planning, have analysed urbanisation and suburbanisation processes in large cities [68]. However, these analyses still lack the combination of these three dimensions for the study of exurbanisation processes in low-density populated areas.

Large cities are expected to keep on growing worldwide. However, a 'cyber-exurbanisation' process can contribute to the mitigation the population imbalance between large cities, with high-density populated areas, and rural areas and small-medium sized cities, with low-density populated areas. The future development and advance of some technological drivers and the desire of some people to live in a place with natural amenities and idealised lifestyles can promote new locations where people wish to live, creating new forms and new human settlements.

Urban population growth is the result of a complex process and represents the consequence of interactions in space and time between environmental and human dimensions [120]. Complex spatial models can provide an epistemological approach to enable us to better recognise it. Furthermore, it can help planners in the decision-making process to clarify unpredictable conditions, to identify, in time and space, plausible future images, and ensure a better quality of the living environment [121], identifying the valuation of different land-use options and socioeconomic settings. Thus, coupling complex spatial models, by creating spatial scenarios of future growth of human settlements, with 
land-use planning policies can better indicate alternatives for future population spatial allocation, and thus mitigate the population imbalance between low- and high-density populated areas.

This commentary can be valuable to create sustainable development strategies for understanding future land-use uncertainties. Moreover, it endeavours to examine directions for future scientific research, and we believe it will further help researchers and decision-makers to better interpret future human settlements based on the new era of technological and environmentally sustainable dimensions.

Funding: This work was developed within the Lithuanian National Ecosystem Services Assessment and Mapping (LINESAM), which has received funding from European Social Fund project LINESAM no. 09.3.3-LMTK-712-01-0104 under a grant agreement with the Research Council of Lithuania (LMTLT).

Conflicts of Interest: The author declares no conflicts of interest.

\section{References}

1. Li, G.; Sun, S.; Fang, C. The varying driving forces of urban expansion in China: Insights from a spatial-temporal analysis. Landsc. Urban Plan. 2018, 174, 63-77. [CrossRef]

2. Holland, J.H. Genetic Algorithms-Computer programs that 'evolve' in ways that resemble natural selection can solve complex problems even their creators do not fully understand. Sci. Am. 1992, 267, 66-72. [CrossRef]

3. Portugali, J. Complexity, Cognition and the City; Springer: Berlin, Germany, 2011.

4. Batty, M. Cities and Complexity: Understanding Cities with Cellular Automata, Agent-Based Models, and Fractals; The MIT Press: Cambridge, MA, USA, 2005.

5. Mandelbrot, B. The Fractal Geometry of Nature; W. H. Freeman and Company: New York, NY, USA, 1982.

6. Heylighen, F. Complexity and Self-organization. In Encyclopedia of Library and Information Sciences; Bates, M., Maak, N., Eds.; CRC Press: Boca Raton, FL, USA, 2008; pp. 133-145.

7. Lorenz, E. Deterministic Nonperiodic Flow. J. Atmos. Sci. 1963, 20, 130-141. [CrossRef]

8. Heylighen, F. Complexity: 5 Questions; Automatic Press: Copenhagen, Denmark, 2007.

9. Lichtenstein, B.B.; Plowman, D.A. The leadership of emergence: A complex systems leadership theory of emergence at successive organizational levels. Leadersh. Q. 2009, 20, 617-630. [CrossRef]

10. Chettiparamb, A. Metaphors in Complexity Theory and Planning. Plan. Theory 2006, 5, 71-91. [CrossRef]

11. Ringland, G. Scenario Planning: Planning for the Future; John Wiley \& Sons: Chichester, UK, 1998.

12. Iba, H. Agent-Based Modelling and Simulation with Swarm, 1st ed.; Chapman and Hall/CRC: Boca Raton, FL, USA, 2013.

13. Fuglsang, M.; Münier, B.; Hansen, H.S. Modelling land-use effects of future urbanization using cellular automata: An Eastern Danish case. Environ. Model. Softw. 2013, 50, 1-11. [CrossRef]

14. Clarke, K.C.; Hoppen, S.; Gaydos, L. A Self-Modifying Cellular Automaton Model of Historical Urbanization in the San Francisco Bay Area. Environ. Plan. B Plan. Des. 1997, 24, 247-261. [CrossRef]

15. Batty, M. The Coronavirus crisis: What will the post-pandemic city look like? Environ. Plan. B Urban Anal. City Sci. 2020, 47, 547-552. [CrossRef]

16. WB. World Bank Open Data. 2019. Available online: https://data.worldbank.org/ (accessed on 20 January 2019).

17. Chen, M.; Zhang, H.; Liu, W.; Zhang, W. The Global Pattern of Urbanization and Economic Growth: Evidence from the Last Three Decades. PLoS ONE 2014, 9, e103799. [CrossRef]

18. Van den Berg, L.; Drewett, L.H.K.L.; Rossi, A.; Vijverberg, C.H.T. Urban. Europe: A Study of Growth and Decline; Pergamon Press: Oxford, UK, 1982.

19. Turner, B.; Lambin, E.; Reenberg, A. The emergence of land change science for global environmental change and sustainability. Proc. Natl. Acad. Sci. USA 2007, 104, 20666-20671. [CrossRef]

20. Robson, J.P.; Berkes, F. Exploring some of the myths of land use change: Can rural to urban migration drive declines in biodiversity? Glob. Environ. Change 2011, 21, 844-854. [CrossRef]

21. Salvati, L.; Zambon, I.; Chelli, F.M.; Serra, P. Review: Do spatial patterns of urbanization and land consumption reflect different socioeconomic contexts in Europe? Sci. Total Environ. 2018, 625, 722-730. [CrossRef] [PubMed]

22. Marques da Costa, E. Cidades Médias e Ordenamento do Território: O caso da Beira Interior. Ph.D. Thesis, Universidade de Lisboa, Lisbon, Portugal, 2001. 
23. Salvati, L.; Carlucci, M. Patterns of Sprawl: The Socioeconomic and Territorial Profile of Dispersed Urban Areas in Italy. Reg. Stud. 2016, 50, 1346-1359. [CrossRef]

24. Gennaio, M.-P.; Hersperger, A.M.; Bürgi, M. Containing urban sprawl-Evaluating effectiveness of urban growth boundaries set by the Swiss Land Use Plan. Land Use Policy 2009, 26, 224-232. [CrossRef]

25. Batty, M.; Xie, Y.; Sun, Z. The dynamics of urban sprawl. Cent. Adv. Spat. Anal. 1999, 15, 1-39.

26. Torrens, P.; Alberti, M. Measuring Sprawl; Centre for Advanced Spatial Analysis (UCL): London, UK, 2000.

27. EEA. Urban sprawl in Europe-The ignored challenge; EEA: Copenhagen, Denmark, 2006.

28. Oueslati, W.; Alvanides, S.; Garrod, G. Determinants of urban sprawl in European cities. Urban Stud. $2015,52$. [CrossRef]

29. Logan, J.R.; Crowder, K.D. Political Regimes and Suburban Growth, 1980-1990. City Community 2002, 1, 113-135. [CrossRef]

30. Bengston, D.N.; Youn, Y.C. Urban containment policies and the protection of natural areas: The case of Seoul's greenbelt. Ecol. Soc. 2006, 11, 3. [CrossRef]

31. Galster, G.; Hanson, R.; Ratcliffe, M.R.; Wolman, H.; Coleman, S.; Freihage, J. Wrestling Sprawl to the Ground: Defining and measuring an elusive concept. Hous. Policy Debate 2001, 12, 681-717. [CrossRef]

32. Jaeger, J.A.G.; Bertiller, R.; Schwick, C.; Kienast, F. Suitability criteria for measures of urban sprawl. Ecol. Indic. 2010, 10, 397-406. [CrossRef]

33. Van Vliet, J.; de Groot, H.L.F.; Rietveld, P.; Verburg, P.H. Manifestations and underlying drivers of agricultural land use change in Europe. Landsc. Urban Plan. 2015, 133, 24-36. [CrossRef]

34. Abrantes, P.; Fontes, I.; Gomes, E.; Rocha, J. Compliance of land cover changes with municipal land use planning: Evidence from the Lisbon metropolitan region (1990-2007). Land Use Policy 2016, 51, 120-134. [CrossRef]

35. Lambin, E.F.; Geist, H.J.; Lepers, E. Dynamics of Land-Use and Land-Cover Change in Tropical Regions. Annu. Rev. Environ. Resour. 2003, 28, 205-241. [CrossRef]

36. Gomes, E.; Banos, A.; Abrantes, P.; Rocha, J. Assessing the effect of spatial proximity on urban growth. Sustainability 2018, 10, 5. [CrossRef]

37. Jackson, R.J.; Kochtitzky, C. Creating a Healthy Environment: The Impact of the Built Environment on Public Health; Sprawl Watch Clearinghouse: Washington, DC, USA, 2003.

38. Nechyba, T.J.; Walsh, R.P. Urban Sprawl. J. Econ. Perspect. 2010, 18, 177-200. [CrossRef]

39. Owusu, G. Coping with Urban Sprawl: A Critical Discussion of the Urban Containment Strategy in a Developing Country City, Accra. Planum J. Urban. 2013, 26, 1-17.

40. Gomes, E.; Banos, A.; Abrantes, P.; Rocha, J.; Kristensen, S.B.P.; Busck, A. Agricultural land fragmentation analysis in a peri-urban context: From the past into the future. Ecol. Indic. 2019, 97, 380-388. [CrossRef]

41. Bhatta, B. Analysis of Urban Growth and Sprawl from Remote Sensing Data; Springer: Berlin/Heidelberg, Germany, 2010; pp. 17-37.

42. Arbury, J. From Urban Sprawl to Compact City-An Analysis of Urban Growth Management in Auckland; University of Auckland, Geography and Environmental Science: Auckland, New Zealand, 2005.

43. Nelson, A.C.; Dueker, K.J. The Exurbanization of America and Its Planning Policy Implications. J. Plan. Educ. Res. 1990, 9, 91-100. [CrossRef]

44. Spectorsky, A.C. The Exurbanites; Lippincott: Philadelphia, PA, USA, 1955.

45. Cadieux, K.V.; Hurley, P.T. Amenity migration, exurbia, and emerging rural landscapes: Global natural amenity as place and as process. GeoJournal 2011, 76, 297-302. [CrossRef]

46. Bürgi, M.; Hersperger, A.M.; Schneeberger, N. Driving forces of landscape change-Current and new directions. Landsc. Ecol. 2004, 19, 857-868. [CrossRef]

47. Golub, A.; Hertel, T.; Lee, H.-L.; Rose, S.; Sohngen, B. The opportunity cost of land use and global potential for greenhouse gas mitigation in agriculture and forestry. Resour. Energy Econ. 2009, 31. [CrossRef]

48. Pielke, R.A. Land Use and Climate Change. Science 2005, 310, 1625-1626. [CrossRef]

49. Steinbuks, J.; Hertel, T. Energy prices will play an important role in determining global land use in the twenty first century. Environ. Res. Lett. 2013, 8. [CrossRef]

50. Matuschke, I. Rapid Urbanization and Food Security: Using Food Density Maps to Identify Future Food Security Hotspots. In Proceedings of the International Association of Agricultural Economists Conference, Beijing, China, 16-22 August 2009. 
51. Bren d'Amour, C.; Reitsma, F.; Baiocchi, G.; Barthel, S.; Güneralp, B.; Erb, K.-H.; Haberl, H.; Creutzig, F.; Seto, K.C. Future urban land expansion and implications for global croplands. Proc. Natl. Acad. Sci. USA 2017, 114, 8939-8944. [CrossRef] [PubMed]

52. De Espindola, G.M.; de Aguiar, A.P.D.; Pebesma, E.; Câmara, G.; Fonseca, L. Agricultural land use dynamics in the Brazilian Amazon based on remote sensing and census data. Appl. Geogr. 2012, 32, 240-252. [CrossRef]

53. Gomes, E.; Abrantes, P.; Banos, A.; Rocha, J.; Buxton, M. Farming under urban pressure: Farmers' land use and land cover change intentions. Appl. Geogr. 2019, 102, 58-70. [CrossRef]

54. Hettig, E.; Lay, J.; Sipangule, K. Drivers of Households' Land-Use Decisions: A Critical Review of Micro-Level Studies in Tropical Regions. Land 2016, 5, 32. [CrossRef]

55. Zscheischler, J.; Rogga, S.; Busse, M. The Adoption and Implementation of Transdisciplinary Research in the Field of Land-Use Science-A Comparative Case Study. Sustainability 2017, 9. [CrossRef]

56. Alexandratos, N.; Bruinsma, J. World Agriculture Towards 2030/2050. The 2012 Revision; Food and Agriculture Organization of the United Nations: Rome, Italy, 2012.

57. Batty, M.; Longley, P. The fractal simulation of urban structure. Environ. Plan. A 1986, 18, 1143-1179. [CrossRef]

58. Newman, M. Complex Systems: A Survey. Phys. Rep. 2009, 79, 10.

59. Waldrop, M. The Emerging Science at the Edge of Order and Chaos; Simon \& Shuster: New York, NY, USA, 1992.

60. Heppenstall, A.; Malleson, N.; Crooks, A. Space, the Final Frontier: How Good are Agent-Based Models at Simulating Individuals and Space in Cities? Systems 2016, 4, 9. [CrossRef]

61. Massotte, P. Behavioural Analysis of a Complex System. Int. J. Adv. Manuf. Technol. 1996, 12, 66-76. [CrossRef]

62. Bennett, D.; McGinnis, D. Coupled and complex: Human-environment interaction in the Greater Yellowstone Ecosystem, USA. Geoforum 2008, 39, 833-845. [CrossRef]

63. Ladyman, J.; Lambert, J.; Wiesner, K. What is a complex system? Eur. J. Philos. Sci. 2011, 3, 33-67. [CrossRef]

64. Magee, C.; de Weck, O. Complex system classification. In Proceedings of the Fourteenth Annual International Symposium of the International Council on Systems Engineering, Toulouse, France, 20-24 June 2004; p. 18.

65. Cotsaftis, M. What Makes a System Complex?-An Approach to Self Organization and Emergence. In From System Complexity to Emergent Properties; Springer: Berlin/Heidelberg, Germany, 2009; Volume 44, pp. 49-99.

66. Lempert, R.J. A new decision sciences for complex systems. Proc. Natl. Acad. Sci. USA 2002, 99 (Suppl. S3), 7309-7313. [CrossRef] [PubMed]

67. Silva, E.; de Roo, G. A Planner's Encounter with Complexity; Routledge: London, UK, 2010.

68. Musa, S.I.; Hashim, M.; Reba, M.N.M. A review of geospatial-based urban growth models and modelling initiatives. Geocarto Int. 2017, 32, 813-833. [CrossRef]

69. Worboys, M. Event-oriented approaches to geographic phenomena. Int. J. Geogr. Inf. Sci. 2005, 19, 1-28. [CrossRef]

70. Couclelis, H. Cellular Worlds: A Framework for Modeling Micro-Macro Dynamics. Environ. Plan. A Econ. Space 1985, 17, 585-596. [CrossRef]

71. Deadman, P.; Brown, R.D.; Gimblett, H.R. Modelling Rural Residential Settlement Patterns with Cellular Automata. J. Environ. Manag. 1993, 37, 147-160. [CrossRef]

72. White, R.; Engelen, G. High-resolution integrated modelling of the spatial dynamics of urban and regional systems. Comput. Environ. Urban Syst. 2000, 24, 383-400. [CrossRef]

73. Mekni, M.; Moulin, B.; Paris, S. Semantically-Enhanced Virtual Geographic Environments for Multi-Agent Geo-Simulation. In Advanced Geo-Simulation Models; Bentham Science: Sharjah, UAE, 2012; pp. 66-91.

74. Anderson, T.; Dragicevic, S. A Geosimulation Approach for Data Scarce Environments: Modeling Dynamics of Forest Insect Infestation across Different Landscapes. ISPRS Int. J. Geo Inf. 2016, 5, 9. [CrossRef]

75. Batty, M.; Heppenstall, A.; Crooks, A.; See, L.M. (Eds.) Agent-Based Models of Geographical Systems; Springer: Berlin, Germany, 2012; Volume 164, pp. 1-15.

76. Blaschke, T.; Merschdorf, H. Geographic information science as a multidisciplinary and multiparadigmatic field. Cartogr. Geogr. Inf. Sci. 2014, 41, 196-213. [CrossRef]

77. Verburg, P.H.; Schot, P.P.; Dijst, M.J.; Veldkamp, A. Land use change modelling: Current practice and research priorities. GeoJournal 2004, 61, 309-324. [CrossRef] 
78. Agarwal, C.; Green, G.M.; Grove, J.M.; Evans, T.P.; Schweik, C.M. A Review and Assessment of Land-Use Change Models: Dynamics of Space, Time, and Human Choice; Department of Agriculture, Forest Service, Northeastern Research Station: Newton Square, PA, USA, 2002; p. 62.

79. Silva, E.; Wu, N. Surveying Models in Urban Land Studies. J. Plan. Lit. 2012, 27, 139-152. [CrossRef]

80. Houet, T.; Schaller, N.; Castets, M.; Gaucherel, C. Improving the simulation of fine-resolution landscape changes by coupling top-down and bottom-up land use and cover changes rules. Int. J. Geogr. Inf. Sci. 2014, 28, 1848-1876. [CrossRef]

81. Viana, C.M.; Rocha, J. Evaluating Dominant Land Use/Land Cover Changes and Predicting Future Scenario in a Rural Region Using a Memoryless Stochastic Method. Sustainability 2020, 12, 4332. [CrossRef]

82. Morgado, P.; Gomes, E.; Costa, N. Competing visions? Simulating alternative coastal futures using a GIS-ANN web application. Ocean. Coast. Manag. 2014, 101, 79-88. [CrossRef]

83. Boavida-Portugal, I.; Ferreira, C.C.; Rocha, J. Where to vacation? An agent-based approach to modelling tourist decision-making process. Curr. Issues Tour. 2017, 20, 1557-1574. [CrossRef]

84. Houet, T.; Verburg, P.H.; Loveland, T.R. Monitoring and modelling landscape dynamics. Landsc. Ecol. 2010, 25, 163-167. [CrossRef]

85. Shahumyan, H.; Williams, B.; Petrov, L.; Foley, W. Regional Development Scenario Evaluation through Land Use Modelling and Opportunity Mapping. Land 2014, 3, 1180-1213. [CrossRef]

86. Silva, E.A.; Clarke, K.C. Calibration of the SLEUTH urban growth model for Lisbon and Porto, Portugal. Comput. Environ. Urban Syst. 2002, 26, 525-552. [CrossRef]

87. Engelen, G. The theory of self-organization and modelling complex urban systems. Eur. J. Oper. Res. 1988, 37, 42-57.

88. Pijanowski, B.C.; Brown, D.G.; Shellito, B.A.; Manik, G.A. Using neural networks and GIS to forecast land use changes: A Land Transformation Model. Comput. Environ. Urban Syst. 2002, 26, 553-575. [CrossRef]

89. Ettema, D.; Jong, K.; Timmermans, H.; Bakema, A. PUMA: Multi-Agent Modelling of Urban Systems Modelling Land-Use Change. In Modelling Land-Use Change; Springer: Berlin, Germany, 2007; Volume 90, pp. 237-258.

90. Wagner, P.; Wegener, M. Urban Land Use, Transport and Environment Models. disP Plan. Rev. 2007, 43, 45-56. [CrossRef]

91. Veldhuisen, J.; Timmermans, H.; Kapoen, L. RAMBLAS: A regional planning model based on the microsimulation of daily activity travel patterns. Environ. Plan. A 2000, 32, 427-443. [CrossRef]

92. Macal, C.M. Everything you need to know about agent-based modelling and simulation. J. Simul. 2016, 10, 144-156. [CrossRef]

93. Gounaridis, D.; Chorianopoulos, I.; Symeonakis, E.; Koukoulas, S. A Random Forest-Cellular Automata modelling approach to explore future land use/cover change in Attica (Greece), under different socio-economic realities and scales. Sci. Total Environ. 2019, 646, 320-335. [CrossRef] [PubMed]

94. Tenedório, J.; Rocha, J. Introductory Chapter: Spatial Analysis, Modelling, and Planning. In Spatial Analysis, Modelling and Planning; IntechOpen: London, UK, 2018; pp. 1-13.

95. UN. Guidelines for Land-Use Planning; UN: New York, NY, USA, 1993.

96. Adams, V.M.; Pressey, R.L.; Álvarez-Romero, J.G. Using Optimal Land-Use Scenarios to Assess Trade-Offs between Conservation, Development, and Social Values. PLoS ONE 2016, 11, e0158350. [CrossRef]

97. Morgado, P. Modelação geográfica de indicadores de desenvolvimento sustentável. Finisterra $2012,37$. [CrossRef]

98. Kurz, T.; Baudains, C. Biodiversity in the Front Yard: An Investigation of Landscape Preference in a Domestic Urban Context. Environ. Behav. 2010, 44, 166-196. [CrossRef]

99. Bertrand, N.; Cremer-Schulte, D.; Perrin, M. Strategic spatial planning and territorial asymmetries. Grenoble and greater geneva: Two Alpine city regions put to the challenge of coherence. J. Alp. Res. 2015, 103. [CrossRef]

100. Philbeck, T.; Davis, N. The Fourth Industrial Revolution: Shaping a new era. J. Int. Aff. 2018, 72, 17-22.

101. Sakr, D. Sustainability and Innovation: The Next Global Industrial Revolution. J. Clean. Prod. 2017, 142, 3355-3356. [CrossRef]

102. García-Florentino, C.; Maguregui, M.; Ciantelli, C.; Sardella, A.; Bonazza, A.; Queralt, I.; Carrero, J.A.; Natali, C.; Morillas, H.; Arana, G.; et al. Deciphering past and present atmospheric metal pollution of urban 
environments: The role of black crusts formed on historical constructions. J. Clean. Prod. 2020, 43, 118594. [CrossRef]

103. Brennand, C.A.R.L.; Filho, G.P.R.; Maia, G.; Cunha, F.; Guidoni, D.L.; Villas, L.A. Towards a Fog-Enabled Intelligent Transportation System to Reduce Traffic Jam. Sensors 2019, 19, 3916. [CrossRef]

104. Ho, H.-C.; Lin, S.-W.; Lee, H.-Y.; Huang, C.-C. Evaluation of a Multi-Objective Genetic Algorithm for Low Impact Development in an Overcrowded City. Water 2019, 11. [CrossRef]

105. Martínez-García, E.; Grossman, V. Explosive dynamics in house prices? An exploration of financial market spillovers in housing markets around the world. J. Int. Money Finance 2020, 101, 102103. [CrossRef]

106. Deutsche Bank. Mapping the World's Prices 2019; Deutsche Bank: London, UK, 2019.

107. Le Goix, R.; Giraud, T.; Cura, R.; Le Corre, T.; Migozzi, J. Who sells to whom in the suburbs? Home price inflation and the dynamics of sellers and buyers in the metropolitan region of Paris, 1996-2012. PLoS ONE 2019, 14, e0213169. [CrossRef]

108. Frank, A.G.; Dalenogare, L.S.; Ayala, N.F. Industry 4.0 technologies: Implementation patterns in manufacturing companies. Int. J. Prod. Econ. 2019, 210, 15-26. [CrossRef]

109. Freeman, L.; Urbaczewski, A. Critical Success Factors for Online Education: Longitudinal Results on Program Satisfaction. Commun. Assoc. Inf. Syst. 2019, 630-645. [CrossRef]

110. Felstead, A.; Henseke, G. Assessing the growth of remote working and its consequences for effort, well-being and work-life balance. New Technol. Work Employ. 2017, 32, 195-212. [CrossRef]

111. Yue, Z.; Ren, H.; Wei, S.; Lin, J.; Gu, M. Angular-momentum nanometrology in an ultrathin plasmonic topological insulator film. Nat. Commun. 2018, 9, 4413. [CrossRef]

112. Zhang, L.; Liang, Y.-C.; Niyato, D. 6G Visions: Mobile ultra-broadband, super internet-of-things, and artificial intelligence. China Commun. 2019, 16, 1-14.

113. Deuten, S.; Gómez Vilchez, J.J.; Thiel, C. Analysis and testing of electric car incentive scenarios in the Netherlands and Norway. Technol. Forecast. Soc. Change 2020, 151, 119847. [CrossRef]

114. IEA. Global EV Outlook 2019; IEA: Paris, France, 2019.

115. Torous, J.; Hsin, H. Empowering the digital therapeutic relationship: Virtual clinics for digital health interventions. npj Digit. Med. 2018, 1, 16. [CrossRef]

116. Castanho, R.A.; Vulevic, A.; Naranjo Gómez, J.M.; Cabezas, J.; Fernández-Pozo, L.; Loures, L.; Kurowska-Pysz, J. Political commitment and transparency as a critical factor to achieve territorial cohesion and sustainable growth. European cross-border projects and strategies. Reg. Sci. Policy Pract. 2019, 11, 423-435. [CrossRef]

117. Sinsel, S.R.; Riemke, R.L.; Hoffmann, V.H. Challenges and solution technologies for the integration of variable renewable energy sources-A review. Renew. Energy 2020, 145, 2271-2285. [CrossRef]

118. Gomes, E.; Banos, A.; Abrantes, P.; Rocha, J.; Schläpfer, M. Future land use changes in a peri-urban context: Local stakeholder views. Sci. Total Environ. 2020, 718, 137381. [CrossRef]

119. Gomes, E.; Abrantes, P.; Banos, A.; Rocha, J. Modelling future land use scenarios based on farmers' intentions and a cellular automata approach. Land Use Policy 2019, 85, 142-154. [CrossRef]

120. Castree, N. The return of nature? Cult. Geogr. 2012, 19, 547-552. [CrossRef]

121. Herold, M.; Couclelis, H.; Clarke, K.C. The role of spatial metrics in the analysis and modeling of urban land use change. Comput. Environ. Urban Syst. 2005, 29, 369-399. [CrossRef]

(C) 2020 by the author. Licensee MDPI, Basel, Switzerland. This article is an open access article distributed under the terms and conditions of the Creative Commons Attribution (CC BY) license (http://creativecommons.org/licenses/by/4.0/). 